
3 Research Square
Preprints are preliminary reports that have not undergone peer review.
They should not be considered conclusive, used to inform clinical practice, or referenced by the media as validated information.

\title{
Trade-off strategies of leaf functional traits of desert halophyte Lycium ruthenicum in the lower reaches of Heihe River, Northwest China: response to soil moisture and salinity
}

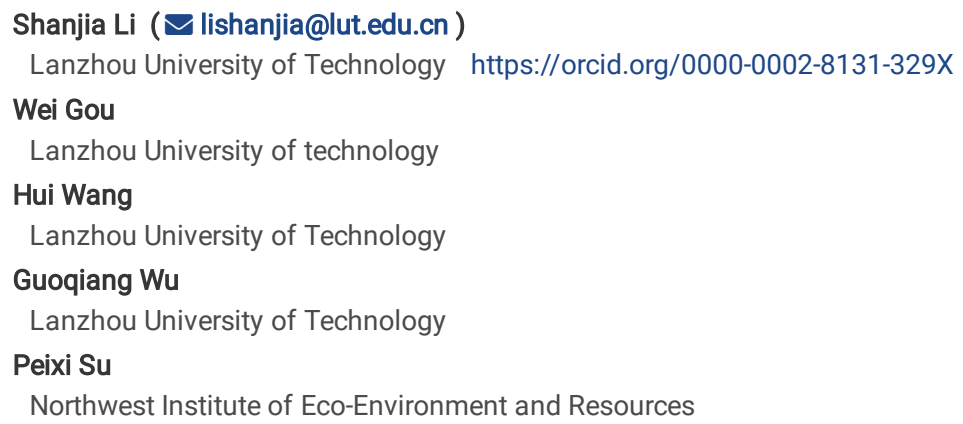




\section{Abstract}

Background: Soil salinization affects plant growth and causes changes in leaf traits. Lycium ruthenicum Murr. is one of the dominant shrubs and halophytes in the lower reaches of the Heihe River in Northwest China. We analyze the trade-off strategies of fourteen leaf functional traits of eight $L$.ruthenicum populations growing at varying distances from the Heihe River, and discussed the effects soil moisture and salinity on leaf functional traits.

Results: Lower nitrogen (N) contents indicated that L.ruthenicum was located at the slow investment-return axis of the species resource utilization graph. Compared to non-saline and very slightly saline sites, populations of slightly saline sites showed higher carbon to nitrogen ratio (C:N). Redundancy analysis (RDA) revealed a relatively strong relationship between leaf functional traits and soil properties, the first RDA axis accounted for $70.99 \%$ and $71.09 \%$ of the variation in $0-40 \mathrm{~cm}$ and $40-80 \mathrm{~cm}$ of soil moisture and salinity. Populations in non-saline and very slightly saline habitats tended to have higher leaf $\mathrm{C}$ content, whereas populations in slightly saline habitats tended to have lower leaf C content, and the discrepancy was evident. Relative importance analysis found that in the $0-40 \mathrm{~cm}$ soil layer, leaf traits variations were mainly influenced by soil moisture (SWC), $\mathrm{HCO}_{3}{ }^{-}$and $\mathrm{CO}_{3}{ }^{2-}$ ions $\mathrm{content}$, while leaf trait variations in the $40-80 \mathrm{~cm}$ soil layer were mainly influenced by $\mathrm{HCO}_{3}{ }^{-}$and $\mathrm{SO}_{4}{ }^{2-}$.

Conclusions: The leaf functional traits of $L$. ruthenicum in this region are mainly restricted by soil $\mathrm{N}$ content. The L.ruthenicum populations formed a pattern of increased C:N ratios and $\mathrm{C}$ content, reduced nitrogen to phosphorus ratio (N:P) and $\mathrm{N}$ content from very slightly saline soil to slightly saline. L.ruthenicum has a foliar resource acquisition method and a resource conservation trade-off with a flexible life history strategy in habitats with drought and salinity stress. In the shallow soil layers, water has a greater effect than salt on leaf trait variation, in both shallow and deep soil layers, $\mathrm{HCO}_{3}{ }^{-}$have a relatively important effect on leaf traits. We believe that these findings will provide some baseline information to facilitate the management and restoration of arid-saline desert ecosystems.

\section{Background}

Plant functional traits are defined as measurable morphological, physiological and phenological properties that are related to individual adaptations [1]. The characteristics, relationships and affection factors of plant functional traits are hot topic in current ecological research, aiming to clearly link the phenotypes differences of individual plants to ecosystem processes and services [2-3]. In the analyses of easy-to-measure functional features, two major trade-offs are immediately identified [4-5]. One of the trade-offs can be explained by the fact that leaves with contrasting features promote rapid access to nutrients in fertile habitats while protecting resources in non-productive habitats [4]. The well-known "leaf economics spectrum" reveals a trade-off between the quick and slow return of investments of nutrients and dry mass that operates independently of biome, growth form, or plant functional type [6]. For instance, leaves with higher nitrogen content tend to have lower leaf mass per unit area and shorter leaf life span, and leaves with larger $A_{\text {max }}$ (the maximum rate of photosynthesis per unit of leaf mass) tend to also have shorter leaf life span [6]. Other suites of related traits have also been recognized that may indicate physical or physiological trade-off strategies [3].

Ecological stoichiometry as an important component of plant functional traits is a comprehensive method for managing quality balances and provides a new perspective for understanding ecosystem process from the individual organism level to the ecosystem level [7]. To study the role of one element in the ecological process, the influence of other elements must be considered at the same time [7-9]. Carbon (C), nitrogen ( $N)$, and phosphorus (P) are the core elements in the study of ecological stoichiometry, and they are also particularly important leaf functional traits. Given the importance of understanding the elemental components and the biogeochemical cycles that are coupled with component-pattern-driven phenotypic plasticity found in terrestrial ecosystems, analyses of C:N:P ratios are increasing [10-14]. Previous studies show that C:N ratios are constrained by variations among different functional groups, with $\mathrm{N}$ content scaling with respect to $\mathrm{C}$ content in foliage $[11,13]$. In addition, the ratios of $\mathrm{C}: \mathrm{N}$ and $\mathrm{C}: \mathrm{P}$ reflect the ability of plants to assimilate $\mathrm{C}$ while simultaneously absorbing $\mathrm{N}$ and $\mathrm{P}$. Comparatively, the ratios of N:P can reflect a dynamic balance between soil nutrients and plant nutrition demands [10,15]. Over the past decade, distribution patterns of $\mathrm{C}, \mathrm{N}$, and $\mathrm{P}$ contents in plant leaves at global or regional scales, as well as environmental factor relationship research in general, have received widespread attention $[12,13,16]$. Recent studies tend to explain the temporal and spatial variability of plant functional traits under adverse conditions (salinity, drought, and frost stress) [17-21].

Among many soil characteristics, moisture and salinity are important conditions that affect plant growth [22]. In arid environments, drought exerts a strong selective pressure on morphological-chemical traits and plant life history strategies $[1,4,23]$. Salinity is one of the major environmental factors limiting plant growth, development, productivity, and distribution patterns [24-26]. Excessive accumulation of salt in the soil imposes physiological limitations on plants, including osmotic stress, ion imbalance, oxidative stress and photosynthesis damaged, thereby affecting plant growth [27-29]. Salt stress is exacerbated by the impact of human over-exploitation and the initial lack of water in the desert-oasis eco-interlaced zone in arid and semi-arid regions [30]. Severe moisture and salinity stress decreases plant growth rate, leaf area, and biomass accumulation [31]. However, previous studies suggest that appropriate saline conditions can enhance the biological carbon fixation of halophytes [32]. Other stoichiometric research in an oasis-desert region also indicates that soil conductivity is highly positively correlated with leaf $\mathrm{C}$ and $\mathrm{N}$ contents [20], but there is a significantly negative correlation between leaf $\mathrm{P}$ content and soil salinity, and conversely, a positive correlation between the ratios of leaf C:P, N:P ratios, and soil salinity [33]. The regression analyses for three functional groups along salinity gradients indicate that salinity decreases leaf $\mathrm{C}: \mathrm{N}$ ratios and increases N:P ratios, but that salinity is not the main driver of leaf C:N:P stoichiometry in halophytes [24]. In summary, plant responses to stress have received attention, possibly due to ecosystem degradation over past decades, but the adaptive strategies of halophytes and their tolerance to drought and salinity stresses are not well understood.

Many studies have shown that Lycium ruthenicum Murr. (Solanaceae) is an important medicinal desert halophyte in arid and saline region [34]. In addition to its nutritive value, $L$. ruthenicum can regulate carbon assimilation and carbon metabolism through morphological changes to adapt to high salt and drought conditions, allowing the colonization of desert saline-alkali soils [35]. L. ruthenicum can prevent soil desertification and reduce soil salinity and alkalinity through special physiological characteristics [36], therefore, it is of great significance to study the functional traits of $L$. ruthenicum in desert saline-alkali 
regions where plant species diversity is low. In this study, we measure the leaf water physiological and ecological stoichiometry traits of eight different $L$. Ruthenicum populations, as well as the soil moisture and salinity of where they were growing, along an approximately $17 \mathrm{~km}$ long north-south transect of the lower reaches of the Heihe River in China. The objective of the study was to explore: (1) the trade-off strategies between leaf functional traits under drought and salinity stress conditions; (2) the relationships between leaf functional traits and soil factors; and (3) Identify the major environmental factors that affecting plant functional traits.

\section{Results}

\section{Leaf functional traits in different populations of $L$. ruthenicum}

In this study, we measured 14 leaf functional traits (Table 2). Among them, TWC, RWC, SLA, SLV, LT, LDMC, Suc, LD were 79.35-88.37\%, 70.41-137.35\%, 5$8 \mathrm{~cm}^{2} \cdot \mathrm{g}^{-1}, 5.36-12.80 \mathrm{~cm}^{3} \cdot \mathrm{g}^{-1}, 1.02-1.62 \mathrm{~mm}, 125.0-197.9 \mathrm{mg} \cdot \mathrm{g}^{-1}, 0.80-1.38 \mathrm{~g} \cdot \mathrm{cm}^{-2}$, and $0.08-0.19 \mathrm{~g} \cdot \mathrm{cm}^{-3}$, respectively. Leaf ecological stoichiometry traits C, $\mathrm{N}$ and $\mathrm{P}$ contents were 307.39-351.78, 8.09-17.82, and 0.62-5.77 $\mathrm{mg} \cdot \mathrm{g}^{-1}$, respectively. Furthermore, $\mathrm{C}: \mathrm{N}, \mathrm{C}: \mathrm{P}$ and $\mathrm{N}: \mathrm{P}$ ratios were 20.28-37.97, 56.85-415.44, and 2.79-17.70, respectively.

We compared the differences between $L$. ruthenicum functional traits at eight different moisture and salinity sites (Table 1) and found that greater leaf thickness appeared in very slightly saline site VII which was significantly different from non-saline Gobi sites I and VI (Table 2). In addition, the larger SLV, Suc, TWC and RWC traits were also observed to appear at saline sites. Conversely, LDMC, LD, and N contents had the lower values in saline sites. Leaf $\mathrm{N}$ concentration was the least variable between different regions, but it still showed the effects of obviously saline stress on L.ruthenicum. Statistical analysis shows that the adaptability of L.ruthenicum N:P to drought and salt stress was more stable among eight populations than C:N and C:P. Moreover, we found that there was no significant difference in the SLA trait values between the eight different habitats, showing that intra-specific variation in SLA at our finer ecological scale was minimal or non-existent.

\section{Correlation between leaf functional traits of $L$. ruthenicum in different habitats}

Correlation coefficients (see Fig.1) between 14 leaf traits of L. ruthenicum showed that LT was significantly positive correlated with Suc, but significantly negative correlated with C content. SLV was highly positive correlated with SLA and both were significantly negative correlated with LD and significantly positive correlated with TWC. LDMC was significantly positive correlated with LD, and both were significantly negative correlated with TWC. Suc was significantly positive correlated with TWC and RWC, but was significantly negative correlated with C content. TWC was significantly positive correlated with $\mathrm{P}$ content, while $\mathrm{P}$ content was significantly negative correlated with N:P and C:P ratios. N:P and C:P ratios were significantly positive correlated with each other, while RWC was highly negative correlated with N:P and C:P ratios.

\section{RDA of leaf functional traits in soil moisture and salinity gradients}

Two RDA maps of different soil layers showed the distribution pattern of traits along the salinity gradients. From non-saline to slightly saline gradients, populations had higher $\mathrm{C}: \mathrm{N}$ ratios, lower $\mathrm{N}$ content, and lower N:P ratios (see RDA vertical axis direction), but the vertical axis (RDA 2) only explained very low proportions of the data. In the horizontal axis, populations growing in high salinity soils had lower C:P than populations growing in lower salinity soils (Fig. 2 , Table 2), while the distribution of other leaf traits didn't change much with environmental gradients. 0-40 cm and 40-80 cm soil properties respectively explained $70.99 \%$ and $71.09 \%$ of leaf traits variation (the sum of the first two axes explained). Permutation tests for all canonical axes were not significant ( 0 $40 \mathrm{~cm}$ RDA, $D f=10, F=1.53, \operatorname{Pr}(>F)=0.31 ; 40-80 \mathrm{~cm} R D A, D f=10, F=1.56, \operatorname{Pr}(>F)=0.29$, Fig. 2). In general, the spatial distribution of the eight populations might be driven by variation in soil chemical characteristics. Populations I, II, III, IV, and VI (see Table1, 2 groups) were close to each other due to their similar soil chemistry, as were populations V and VII. However, population VIII was located away from the other populations, so its soil properties likely differed from the other locations.

\section{Relative importance of soil factors to leaf functional traits variation}

We were not only interested in the effects of total soil salinity on leaf functional traits, but also in the exploration of which salt ions affect plant functional trait formation and variation the most. In general, moisture, salinity, and eight major ions corresponded to leaf character variation in different amplitudes. In the 0 $40 \mathrm{~cm}$ soil layer, leaf traits patterns were mainly influenced by $\mathrm{SWC}, \mathrm{HCO}_{3}{ }^{-}$and $\mathrm{CO}_{3}{ }^{2-}$, and their relative importance values for the fourteen leaf traits are shown in Fig. 3. The relative contribution of 0-40 cm layer SWC to all but the LT trait was more than $17 \%$. SWC had a effect on C:P ratios, with an importance of $34 \%$. $\mathrm{HCO}_{3}{ }^{-}$was more than $13 \%$ important for all traits except SLV and $\mathrm{N}$ content. $\mathrm{CO}_{3}{ }^{2}$ was less important for traits than $\mathrm{SWC}$ and $\mathrm{HCO}_{3}$. Soil salinity and other ions contributed relatively little to leaf properties. In the $40-80 \mathrm{~cm}$ layer, $\mathrm{HCO}_{3}{ }^{-}$and $\mathrm{SO}_{4}{ }^{2-}$ were two main drivers for trait differentiation. The relative importance of $\mathrm{HCO}_{3}{ }^{-}$for all trait patterns was higher than $20 \%$, and its influence on $\mathrm{P}$ content was up to $52 \%$. The influence of $\mathrm{SO}_{4}{ }^{2-}$ on traits was above $12 \%$, except for LDMC, LD, and $\mathrm{N}$ content, which were below $10 \%$.

\section{Discussion}

\section{Variations of $L$. ruthenicum leaf functional traits in the lower reaches of Heihe River}

This study shows that the desert halophyte L. ruthenicum is characterized by low leaf SLA, LDMC, C content, N content and N:P ratios, as well as high LT, Suc, $\mathrm{P}$ content and C:N ratios. SLA is one of the key leaf traits related to plant carbon uptake strategy [37], it could reflect the distribution of plants and their adaptation to different habitats [38]. LDMC mainly reflects the ability of plants to retain nutrients [39]. In addition, SLA and LDMC are the best variables for classifying plant species on the plant resource utilization classification axis [6]. This paper showed that $L$. ruthenicum is a resource reservation species due to 
its lower SLA and N content, and higher C:N ratio. This also indicates that $L$. ruthenicum is in the "slow-return" end of the spectrum. Plants that invest in high LMA (Leaf mass per area) have a slower photosynthetic rate, but longer leaf life, so their slower income (carbon absorption) rate can be compensated by a longer income stream $[6,40]$. Furthermore, SLA and LDMC are two important soil-fertility predictors in addition to leaf N and P contents and N:P ratios [15,4143]. The combination of these predictors indicates that soil fertility is lower in the Ejina desert area in the lower reaches of the Heihe River and that the growth of $L$. ruthenicum is mainly restricted by $\mathrm{N}$ content. Prior studies that note the importance of $\mathrm{C}: \mathrm{N}$ and $\mathrm{C}: \mathrm{P}$ ratios can effectively reflect the balance between competitive and defensive strategies [33]. When $\mathrm{N}$ and $\mathrm{P}$ contents are higher, $\mathrm{C}: \mathrm{N}$ and $\mathrm{C}: \mathrm{P}$ ratios are comparatively lower. Plants will apply competitive strategies at high photosynthetic rates. Conversely, when $\mathrm{C}$ content is higher, C:N and C:P ratios are also higher, showing how plants adopt a strong defensive strategy under low photosynthetic rates [44-45]. The results of this study indicate that $L$. ruthenicum has a flexible strategy in different desert saline habitats: when soil salinity is higher, foliar $\mathrm{N}$ is lower, and the $\mathrm{C}: \mathrm{N}$ ratio is large, a defensive strategy is adopted; when $\mathrm{N}$ contents are higher and the C:N ratio is lower, a competitive survival strategy is adopted. Leaf thickness (LT) is generally considered to be a very important leaf trait characteristic, which may be related to leaf life span, stress tolerance, and litter decomposition rate [46-47]. Osmond et al. found that plant leaves are thicker in nutrient-poor environments, the LT pattern presented by Osmond et al. is consistent with previous research [48]. In order to adapt to harsh environments, succulent plants produce a large number of parenchyma cells, in organs such as the leaves and stems. In eight different habitats, L. ruthenicum shows a significant amount of succulence (Suc) used to store moisture in the arid, low-rainfall environments of the Ejina desert. All eight $L$. ruthenicum populations had higher $\mathrm{P}$ content compared 753 terrestrial plant species in China $[13,24]$, this shows that local minerals decomposed faster to ensure that enough young leaves were produced to reduce the accumulation of toxic salt ions on each leaf. The leaves of $L$. ruthenicum belong to the succulent foliage group, and the higher water content (TWC) of a succulent, the more drought-tolerant it is [49]. SLV is an important leaf trait according to the leaf characteristics of desert plants. RWC reflects the resistance of plants to dehydration: higher RWC leads to stronger resistance to dehydration, since the leaves have higher osmotic adjustment functions.

\section{Trade-offs between functional traits of $L$. ruthenicum}

The existence of a fundamental trade-off between the rapid acquisition and the efficient conservation of resources has been discussed in the ecological literature for more than forty years. However, it was only over the course of the last two decades that the availability of large data sets has allowed for the precise quantification and identification of the trait syndromes that can be used to characterize trade-offs for a wide variety of plants. For example, species with small SLA have thicker leaves or denser tissues, which allows for the maintenance of leaf function or the delaying leaf death under very dry conditions.

Some fundamental relationships found in leaf economics spectrum research include a significantly positive correlation between LT and Suc, which confirms that succulent plants employ a water conservation strategy [46]. While a significantly negative correlation has been found between LT and C content, this can be related to thicker leaves cause a decrease in the SLA which affects carbon acquisition [50]. Some literature reports that SLA is actually a combination of leaf tissue density (LD) and leaf thickness (LT), since leaf tissue density is significantly positive correlated with leaf dry matter content (LDMC), leading to the equation: $S L A=1 /(L D \times L T) \approx 1 /(L D M C \times L T)$ [50]. This paper did not show a significant relationship between SLA and LT, but demonstrated that SLA had a strongly negative correlation with LDMC and LD. The significantly negative correlation between LT and C content, as well as between SLA (SLV) and LD (LDMC), indicates a trade-off between resource acquisition and resource conservation under drought and saline conditions.

LDMC and LD are positively correlated, with both being significantly negative correlated with TWC. Negative correlation of TWC, RWC and LDMC expresses another trade-off between the intracellular water content and nutrient accumulation due to photosynthetic $\mathrm{CO}_{2}$ assimilation, showing that leaf water content is a useful indicator of plant water balance. Suc is significantly positive correlated with TWC, RWC and P content, but strongly negatively correlated with C content. This confirms that leaf succulence can improve the energy returns from leaf investment by replacing expensive carbon structures with water [51].

\section{To what extent does soil moisture and salinity affect leaf functional traits?}

In contrast to significant trait correlation patterns, there are only a few significant differences in the leaf morphological traits and C:N:P stoichiometry of desert halophytes with different salinity and moisture habitats. In this paper, we found that $\mathrm{SWC}$ and $\mathrm{HCO}_{3}{ }^{-}$in shallow soil layers is a good predictor of leaf traits. Between them, SWC has larger contributions to leaf P content, N:P ratios and C:P ratios while $\mathrm{HCO}_{3}{ }^{-}$has the greatest impact on LDMC, these can be inferred from previous research: in desert ecosystems, lower SWC coupled with higher soil alkalinity acts to decrease both soil N and P availability [52]. Due to this, SWC has a great impact on the levels of leaf $\mathrm{P}$ and $\mathrm{N}: \mathrm{P}$, and $\mathrm{HCO}_{3}{ }^{-}$affects the production of leaf dry matter content. The result was supported by other observations [53].The changing C:P pattern along environmental gradients suggested that $L$. ruthenicum had a flexible life strategy under different environments. In the deeper soil layer, $\mathrm{HCO}_{3}{ }^{-}$, followed by $\mathrm{SO}_{4}{ }^{2-}$, mainly influences leaf functional traits. In the RDA diagram, deep soil SWC have a negative effect on leaf $\mathrm{N}$ content and N:P, but had a positive effect on leaf C:N. SWC does not obviously influence other functional traits. At the same time, the effects of soil salinity also converged with SWC. It can be said the hydraulic properties required for plant safety at higher salinity are at the expense of lower growth rates [54]. People already know a lot about the effects of salt stress on plants. The common sense is that salt stress reduces some transaminase activities, reduces plant $\mathrm{N}$ content, and damages plant growth [55]. Therefore, the carbon fixation ability of the blade will also be reduced significantly, which is consistent with the low leaf $\mathrm{C}$ content phenomenon shown in this paper. Many studies have confirmed that salt stress, especially chloride salt stress, will inhibit plant's $\mathrm{NO}_{3}{ }^{-}$absorption, so the $\mathrm{NO}_{3}{ }^{-}$content in a plant's leaves will decrease during salt stress [56-57]. However, some other studies have shown that the $\mathrm{N}$ content of succulent plants becomes larger as the salinity increases [24]. This discrepancy will require additional research in the future to resolve.

Salt stress limits the growth of halophytes through adverse effects on various physiological and biochemical processes. Conversely, halophytes respond to increased salinity by expanding in diversity [28]. Salinization consists of an accumulation of water-soluble salts in the soil, including the ions of $\mathrm{K}^{+}$, $\mathrm{Mg}^{2+}$, $\mathrm{Ca}^{2+}, \mathrm{Cl}^{-}, \mathrm{SO}_{4}{ }^{2-}, \mathrm{CO}_{3}{ }^{2-}, \mathrm{HCO}_{3}{ }^{-}$and $\mathrm{Na}^{+}$. We tried to analyze this process using salt ions at different depths of soil. The RDA results show that SWC, $\mathrm{HCO}_{3}{ }^{-}$, $\mathrm{CO}_{3}{ }^{2-}, \mathrm{SO}_{4}{ }^{2-}$ and $\mathrm{Cl}^{-}$can explain the variation of functional traits well. Surprisingly, $\mathrm{Na}^{+}$content could not explain the variation significantly, despite the importance of $\mathrm{Cl}^{-}$and $\mathrm{Na}^{+}$as mentioned in many salt stress studies [58-60]. According to our current knowledge, the soluble salts in the lower reaches of the

Page $4 / 12$ 
Heihe River Basin are mainly $\mathrm{Na}^{+}, \mathrm{HCO}_{3} ; \mathrm{SO}_{4}{ }^{2-}$ and $\mathrm{Ca}^{2+}[61]$. However, there are few studies showing how these ions affect leaf functional traits and trade-off strategies, which may be a direction for future research.

\section{Conclusions}

L. ruthenicum has a foliar resource acquisition and resource conservation trade-off with a flexible life history strategy in habitats with drought and salinity gradients. In shallow soils in saline-stressed arid environments, water has a greater effect than salt for leaf trait variation. In both shallow and deep soil layers, $\mathrm{HCO}_{3}{ }^{-}$ions have a relatively large effect on leaf properties. However, other larger scale studies are needed to determine the drivers of functional characteristics.

We concluded from our findings that: (1) the patterns of leaf functional traits in the desert halophyte $L$. ruthenicum in arid and saline environments have a tendency to display lower leaf SLA, LDMC, C, N content and N:P ratios, but higher LT, Suc, P content and C:N ratios, with leaf average N:P ratios <14, showing that soil fertility in the Ejina Desert is limited by nitrogen; (2) leaf traits of L.ruthenicum populations vary significantly according to different soil environments in the habitats; and (3) L. ruthenicum has a foliar resource utilization trade-off with a flexible life history strategy in order to survive in environments with drought and salinity gradients.

\section{Methods}

\section{Study area}

The Heihe River is an inland river located in an extremely arid and fragile ecological environment in northwestern China, this area have extreme arid climate, wind erosion, overgrazing and sand burial, which extends from the upstream area to the downstream area and forms unique desert ecosystem and species composition [62]. The Ejina desert area is located in the lower reaches of the Heihe River Basin. According to the data of the Ejina Weather Station from 1957 to 2011 , the annual average temperature is $8.77^{\circ} \mathrm{C}$, the relative humidity is $33.9 \%$, annual precipitation is $37.40 \mathrm{~mm}$, and the annual evaporation is 3390.26 $\mathrm{mm}$. In environments with low precipitation in the Ejina desert area, the water supply mainly comes from the Heihe River Basin. The plant communities are characterized by low species diversity, being mainly composed of drought- and salt-tolerant desert plants that are distributed throughout the Heihe River and the lake plains of Ejina Banner, the main shrub species are: Tamarix chinensis, Lycium ruthenicum, Nitraria tangutorum and Alhagi sparsifolia [63], among them, the coverage of Lycium ruthenicum reaches about $20 \%$. The soil of the entire Heihe River series contains brown calcium, desert calcium, salt and sand [62].

\section{Sampling protocol and community characteristics}

This study was conducted in early August 2018 within a $17 \mathrm{~km}$ long north to south transect in the lower reaches of the Heihe River Basin. The nearest two of the eight sampling sites were $0.5 \mathrm{~km}$ apart, and the farthest straight line distance was $10 \mathrm{~km}$. All collected plant materials were in a unified development stage, that is in August when the biomass was the largest. The study area was flat and far from any villages. We selected eight different populations of $L$. ruthenicum growing in different moisture and salinity conditions from near to far and vertical with the main river channel. The main distribution areas and different plant habitat types are shown in Table 1. Three plots $(5 \times 5 \mathrm{~m})$ were established within each selected population and their geographic information (latitude, longitude) was recorded with the eXplorist 510GPS device (Magellan, USA). Fully expanded mature leaves ( $>30$ ) at sunny side were randomly collected from 15 individuals for each L.ruthenicum population, and all foliage sampled from 3 plots were mixed as one independent sample for further analysis. There were not any signs of herbivory or pathogen infestation on the leaves.

\section{Determination of leaf water physiological and stoichiometric traits}

Calipers with an accuracy of $0.02 \mathrm{~mm}$ were used to measure leaf thickness (LT, mm). Leaf area was determined via a combination of an EPSON DS-1610 scanner and the ImageJ software [64]. Specific leaf area (SLA) was calculated as leaf area per dry mass, specific leaf volume (SLV, leaf volume per unit dry mass) was determined by a drainage method using a $10 \mathrm{~mL}$ cylinder, the specific operation was to inject an appropriate volume of purified water, put in the chopped leaves, and observed the volume of the liquid level rising. Leaf dry matter content (LDMC) calculated by leaf dry mass per unit fresh mass. The degree of leaf succulence was measured by subtracting the dry weight from the $6 \mathrm{~h}$ saturated fresh weight, then dividing the resulting number by the surface area (Suc, $\mathrm{g} \cdot \mathrm{cm}^{-2}$ ). Leaf tissue density (the ratio of leaf dry weight to volume, LD, $\mathrm{g} \cdot \mathrm{cm}^{-3}$ ), relative water content (RWC, \%), and total water content (TWC, \%) were determined by drying. Except for the LT measurement performed in the field, the other leaves were divided into two groups. One group was used to measure SLA and SLV, and the other group was used to measure moisture and other properties. Leaf samples were then brought back to the laboratory and dried at $80^{\circ} \mathrm{C}$ for 48 hours to reach a constant weight in order to measure the other characteristics. Dried leaves were ground to a $0.15 \mathrm{~mm}$ powder using a sample pulverizer in order to measure the carbon (C), nitrogen $(\mathrm{N})$ and phosphorus $(\mathrm{P})$ contents and calculate the stoichiometric ratio. $\mathrm{C}$ content was determined using the $\mathrm{K}_{2} \mathrm{Cr}_{2} \mathrm{O}_{7}-\mathrm{H}_{2} \mathrm{SO}_{4}$ external heating method in an oil bath. $\mathrm{N}$ content was determined by the semi-automatic Kjeldahl procedure, which involves digestion with concentrated $\mathrm{H}_{2} \mathrm{SO}_{4}$ followed by measurement of $\mathrm{NH}_{3}$ on an auto analyzer (Hanon $\mathrm{K} 9840$, Jinan, China). P content was determined by digestion with $\mathrm{H}_{2} \mathrm{SO}_{4}-\mathrm{H}_{2} \mathrm{O}_{2}$ followed by measurement with the molybdenum antimony method.

\section{Measurement of soil moisture, salinity and ion contents}

Three soil plots were taken near the growth point of each L.ruthenicum population, and then mixed 0-40 cm and $40-80 \mathrm{~cm}$ soil layer samples respectively. One (pooled) soil sample was taken in each of the plots. These soil samples were taken next to the plant individuals that were used for sampling of leaves and then pooled per plot. Samples were collected from an area after 7-10 rainless days had passed. The samples were first passed through a $2 \mathrm{~mm}$ screen to remove roots and other impurities, and then dried at $80^{\circ} \mathrm{C}$ for soil moisture content (SWC) analysis. Electrical conductivity (EC) was measured using a DDS307a portable conductivity meter (Leici Instrument, Shanghai China). We had previously established the standard curve between the soil salinity and electrical 
conductivity of saline-alkali soil in the study area as $y=217.73 x-22.723\left(R^{2}=0.994\right)$, which was used to calculate soil salinity. The unit of soil salinity was $\mathrm{g} \cdot \mathrm{kg}^{-1}$. Soil samples were analyzed within 20 days of collection for carbonate $\left(\mathrm{CO}_{3}{ }^{2-}\right)$, bicarbonate $\left(\mathrm{HCO}_{3}{ }^{-}\right)$, chloride $\left(\mathrm{Cl}^{-}\right)$, sulfate $\left(\mathrm{SO}_{4}{ }^{2-}\right)$, sodium $\left(\mathrm{Na}^{+}\right)$, potassium $\left(\mathrm{K}^{+}\right)$, calcium $\left(\mathrm{Ca}^{2+}\right)$ and magnesium $\left(\mathrm{Mg}^{2+}\right)$ content following the methods described by the US Salinity Laboratory Staff [65]. Specifically, we used this method to measure the total concentration of soil ions rather than the actual concentration available to plants.

\section{Statistical analysis}

One-way analyses of variance were conducted using the SPSS 19.0 Software to compare site characteristics between sites as well as leaf functional traits between populations, post hoc Turkey HSD tests and Levene Statistic were used to check for variance homoscedasticity, sig $>0.05$. The Shapiro-Wilk test was performed to check for data normality. R3.5.2 was used for RDA to check the distribution pattern of plant functional traits in the environmental gradients of different soil layers. Trait data was processed by Hollinger method, and soil data was logarithmic transformed before computing the RDA. Pearson correlations between different plant functional traits were performed using the Performance Analytics package of the R statistical software [66]. "Relative importance analysis" refers to the quantification of an individual regression's contribution to a multiple regression model [67].

\section{Abbreviations}

LT: leaf thickness (mm); SLA: specific leaf area $\left(\mathrm{cm}^{2} \cdot \mathrm{g}^{-1}\right)$; SLV: specific leaf volume $\left(\mathrm{cm}^{3} \cdot \mathrm{g}^{-1}\right)$; LDMC: leaf dry matter content $\left(\mathrm{mg} \cdot \mathrm{g}^{-1}\right)$; Suc: succulence $\left(\mathrm{g} \cdot \mathrm{cm}{ }^{-2}\right)$; LD: leaf tissue density $\left(\mathrm{g} \cdot \mathrm{cm}^{-3}\right)$; TWC: Total water content (\%); RWC: relative water content (\%); C content: leaf carbon content (mg $\left.\mathrm{g}^{-1}\right)$; $\mathrm{N}$ content: leaf nitrogen content $\left(\mathrm{mg} \cdot \mathrm{g}^{-1}\right) ; \mathrm{P}$ content: leaf phosphrous content $\left(\mathrm{mg} \cdot \mathrm{g}^{-1}\right)$.

\section{Declarations}

\section{Authors' contributions}

SJL conceived and designed the experiments and revised the first draft; WG analyzed the data and wrote the draft; HW and WG performed experiments; GQW and PXS guided writing and participated in the survey. All authors read and approved the final manuscript.

\section{Acknowledgements}

We would like to thank all the people involved in this project at the Heihe River station and the reviewers who provided constructive comments. We would all so like to thank Qiuwei Zhang for the modification of the manuscript language.

\section{Availability of data and materials}

All the data were summarized in the manuscript itself. The datasets are available from the corresponding author on reasonable request.

\section{Competing interests}

The authors declare that they have no competing interests.

\section{Funding}

This research was funded by National Natural Science Foundation of China grant number 41961007; Gansu Provincial Key Research and Development Program grant number 18YF1FA066; Lanzhou Science and Technology Development Program grant number 2017-4-94.

\section{Ethics approval and consent to participate}

There was no requirement to seek ethical approval to carry out the work described above.

\section{Consent for publication}

Not applicable.

\section{Author details}

${ }^{1}$ School of Life Science and Engineering, Lanzhou University of Technology, Lanzhou 730050, China; ${ }^{2}$ Key Laboratory of Land Surface Process and Climate Change in Cold and Arid Regions, Northwest Institute of Eco-Environment and Resources, Chinese Academy of Sciences, Lanzhou 730000, China.

\section{References}

1. Violle, C.; Navas, M.L.; Vile, D.; Kazakou, E.; Fortunel, C.; Hummel, I.; Garnier, E. Let the concept of trait be functional. Oikos 2007, 116, 882-892.

2. Bernhardt-Römermann, M.; Römermann, C.; Nuske, R.; Parth, A.; Klotz, S.; Schmidt, W.; Stadler, J. On the identification of the most suitable traits for plant functional trait analyses. Oikos 2008, 117, 1533-1541.

3. Westoby, M.; Wright, I. J. Land-plant ecology on the basis of functional traits. Trends Ecol Evol 2006, 21, 261-268.

4. Díaz, S.; Hodgson, J. G.; Thompson, K.; Cabido, M. The plant traits that drive ecosystems: evidence from three continents. J Veg Sci 2004, $15,295-304$. 
5. Pierce, S.; Bottinelli, A.; Bassani, I.; Ceriani, R. M.; Cerabolini, B. E. L. How well do seed production traits correlate with leaf traits, whole-plant traits and plant ecological strategies? Plant Ecol 2014, 215, 1351-1359.

6. Wright, I. J.; Reich, P. B.; et al. World-wide leaf economics spectrum. Nature 2004, 428, 821-827.

7. Sterner, R. W.; Elser, J. J. Ecological stoichiometry: the biology of elements from molecules to the biosphere. 2002, Princeton University Press, Princeton.

8. Hessen, D. O.; Ágren, G. I.; Anderson, T. R.; Elser, J. J.; de Ruiter, P. C. Carbon sequestration in ecosystems: the role of stoichiometry. Ecology 2004, 85, 1179-

9. Ágren, G. I.; Weih, M. Plant stoichiometry at different scales: element concentration patterns reflect environment more than New Phytol 2012, 194, 944952.

10. Güsewell, S. N:P ratios in terrestrial plants: variation and functional significance. New Phytol 2004, 164, $243-266$.

11. McGroddy, M. E.; Daufresne, T.; Hedin, L. O. Scaling of C:N:P stoichiometry in forest worldwide: implications of terrestrial redfield-type ratios. Ecology 2004, 85, 2390-2401.

12. Reich, P. B.; Oleksyn, J. Global patterns of plant leaf N and P in relation to temperature and latitude. P Natl Acad Sci USA 2004, 101, 11001-11006.

13. Han, W. X.; Fang, J. Y.; Guo, D. L.; Zhang, Y. Leaf nitrogen and phosphorus stoichiometry across 753 terrestrial plant species in New Phytol 2005, 168, 377385.

14. He, J. S.; Fang, J. Y.; Wang, Z. H.; Guo, D. L.; Flynn, D. F.; Geng, Z. Stoichiometry and large-scale patterns of leaf carbon and nitrogen in the grassland biomes of China. Oecologia1 2006, 49, 115-122.

15. Koerselman, W.; Meuleman, A. F. M. The vegetation N:P Ratio: a new tool to detect the nature of nutrient limitation. J Appl Ecol 1996, $33,1441-1450$.

16. He, J. S.; Wang, L.; Flynn, D. F. B.; Wang, X.P.; Ma, W. H.; Fang, J. Y. Leaf nitrogen: phosphorus stoichiometry across Chinese grassland biomes. Oecologia $2008,155,301-310$.

17. Xu, G. Q.; Yan, L.; Hao, X. Seasonal variation in plant hydraulic traits of two co-occurring desert shrubs, Tamarix ramosissima and Haloxylon ammodendron, with different rooting patterns. Ecol Res 2011, 26, 1071-1080.

18. Zhang, L.; Zhang, G. W.; Wang, Y. H.; Zhou, Z. G.; Meng, Y. L.; Chen, B. L. Effect of soil salinity on physiological characteristics of functional leaves of cotton plants. J Plant Res 2013, 126, 293-304.

19. Wang, N.; Gao, J.; Zhang, S. Q.; Wang, G. X. Variations in leaf and root stoichiometry of nitraria tangutorum along aridity gradients in the Hexi Corridor, Northwest China. Contemp Probl Ecol 2014, 7, 308-314.

20. Zhang, K.; Su, Y. Z.; Liu, T. N.; Wang, T. Leaf C:N:P stoichiometrical and morphological traits of Haloxylon ammodendron over plantation age sequences in an oasis-desert ecotone in North China. Ecol Res 2016, 31, 449-457.

21. Bucher, S. F.; Robert, F.; Buchner, O.; Neuner, G.; Rosbakh, S.; Leiterer, M.; Roemermann, C. Temporal and spatial trade-offs between resistance and performance traits in herbaceous plant species. Environ Exp Bot 2019, 157, 187-196.

22. Arndt, S. K. Integrated research of plant functional traits is important for the understanding of ecosystem processes. Plant Soil 2006, 285, 1-3.

23. Niu, K.; Zhang, S.; Zhao, B.; Du, G. Linking grazing response of species abundance to functional traits in the Tibetan alpine meadow. Plant Soil 2010, 330 , 215-223.

24. Wang, L. L.; Zhao, G. X.; Li, M.; Zhang, M. T.; Zhang, L. F.; Zhang, X. F.; An, L. Z.; Xu, S. J. C:N:P stoichiometry and leaf traits of halophytes in an arid saline environment, Northwest China. Plos One 2015,10, e0119935. https://doi.org/10.1371/journal.pone.0119935.

25. Li, J. Y.; Zhao, C. Y.; Li, J.; Yan, Y. Y.; Yu, B.; Han, M. Growth and leaf gas exchange in Populus euphratica across soil water and salinity gradients. Photosynthetica 2013, 51, 321-329.

26. Lu, Y. W.; Miao, X. L.; Song, Q. Y.; Peng, S. M.; Duan, B. L. Morphological and ecophysiological plasticity in dioecious plant Populus tomentosa under drought and alkaline stresses. Photosynthetica 2018, 56, 1353-1364.

27. Shabala, S.; Munns, R. Salinity stress: physiological constraints and adaptive mechanisms. Plant Stress Physiology 2012. https://doi.org/10.1079/9781845939953.0059.

28. Flowers, T. J.; Colmer, T. D. Salinity tolerance in halophytes. New Phytol 2008, 179, 945-963.

29. Munns, R.; Tester, M. Mechanisms of salinity tolerance. AnnuRev Plant Biol 2008, 59, 651-681.

30. Wang, Y.; Li, Y. Land exploitation resulting in soil salinization in a desert-oasis ecotone. Catena 2013, 100, 50-56. https://doi.org/10.1016/j.catena.2012.08.005.

31. Rodríguez, P.; Torrecillas, A.; Morales, M. A.; Ortuno, M. F.; Sánchez-Blancoa, M. J. Effects of $\mathrm{NaCl}$ salinity and water stress on growth and leaf water relations of Asteriscus maritimus Environ Exp Bot 2005, 53, 113-123.

32. Sun, X.; Gao, Y.; Wang, D.; Chen, J.; Zhang, F.; Zhou, J.; Yan, X.; Li, Y. Stoichiometric variation of halophytes in response to changes in soil salinity. Plant Biology 2017, 19, 360-367.

33. Rong, Q. Q.; Liu, J. T. Cai, Y. P.; Lu, Z. H.; Zhao, Z. Z.; Yue, W. C.; Xia, J. X. Leaf carbon, nitrogen and phosphorus stoichiometry of Tamarix chinensis (Lour). in the Laizhou Bay coastal wetland, China. Ecol Eng 2015, 76, 57-65.

34. Zhao, J.; Xu, F.; Ji, T.; Li, J. A New Spermidine from the Fruits of Lycium ruthenicum. Chem Nat Compd 2014, 50, 880-883.

35. Wei, Y.; Xu, X.; Tao, H.; Wang, P. Growth performance and physiological response in the halophyte Lycium barbarum grown at salt-affected soil. Ann Appl Biol 2006, 149, 263-269.

36. Zheng, J.; Ding, C. X.; Wang, L. S.; Li, G. L.; Shi, J. Y.; Li, H.; Wang, H. L.; Suo, Y. R. Anthocyanins composition and antioxidant activity of wild Lycium ruthenicum (Murr). from Qinghai-Tibet Plateau. Food Chem 2011, 126, 859-865. 
37. Wright, I. J.; Westoby, M.; Reich, P. B. Convergence towards higher leaf mass per area in dry and nutrient-poor habitats has different consequences for leaf life span. J Ecol 2002, 90, 534-543.

38. Burns, K. C. Patterns in specific leaf area and the structure of a temperate heath community. Divers Distrib 2004, 10, 105-112.

39. Saura-Mas, S.; Lloret, F. Leaf and shoot water content and leaf dry matter content of mediterranean woody species with different post-fire regenerative strategies. Ann Bot 2007, 99, 545-554.

40. Westoby, M.; Falster, D. S.; Moles; A, T.; Vesk, P. A.; Wright, I. J. Plant ecological strategies: some leading dimensions of variation between species. Annu Rev Ecol Syst 2002, 33, 125-159.

41. Wilson, P. J.; Thompson, K.; Hodgson, J. G. Specific leaf area and leaf dry matter content as alternative predictors of plant strategies. New Phytol 1999, $143,155-162$.

42. Kleyer, M.; Bekker, R. M.; Knevel, I. C.; et al. The LEDA Traitbase: a database of life-history traits of the Northwest European flora. J Ecol 2008, 96, 12661274.

43. Hodgson, J. G.; Marti, G. M.; et al. Is leaf dry matter content a better predictor of soil fertility than specific leaf area? Ann Bot 2011, 108, $1337-1345$.

44. Poorter, L.; Bongers, F. Leaf traits are good predictors of plant performance across 53 rain forest species. Ecology 2006, 87, 1733-

45. Shipley, B.; Lechowicz, M. J.; Wright, I.; Reich, P. B. Fundamental trade-offs generating the worldwide leaf economics spectrum. Ecology 2006, 87, 535-

46. Morandeira, N. S.; Kandus, P. Plant functional types and trait values in the Paraná River floodplain: modelling their association with environmental features. Flora-Morphology Distribution Functional Ecology of Plants 2016, 220, 63-73.

47. Reich, P. B.; Walters, M. B.; Ellsworth, D. S. From tropics to tundra: global convergence in plant functioning. P Natl Acad Sci USA 1997, $94,13730-13734$.

48. Osmond, C. B.; Austin, M. P.; Berry, J. A.; Billings, W. D.; Boyer, J. S.; Dacey, J. W. H.; Nobel, P. S.; Smith, S. D.; Winner, W. E. Stress physiology and the distribution of plants. Bioscience 1987, 37, 38-48.

49. Marenco, R. A.; Antezana-Vera, S. A.; Nascimento, H. C. S. Relationship between specific leaf area, leaf thickness, leaf water content and SPAD-502 readings in six Amazonian tree species. Photosynthetica 2009, 47, 184-190.

50. Shipley, B.; Vu, T. T. Dry matter content as a measure of dry matter concentration in plants and their parts. New Phytol 2002, $153,359-364$.

51. Shipley, B. Structured interspecific determinants of specific leaf area in 34 species of herbaceous angiosperms. FunctEcol 1995, 9, 312-319.

52. He, M.; Dijkstra, F. A.; Zhang, K.; et al. Leaf nitrogen and phosphorus of temperate desert plants in response to climate and soil nutrient availability. Sci Rep $2014,4,6932$.

53. Zhang, B.; Gao, X. P.; Li, L.; Lu, Y.; Shareef, M.; Huang, C. B.; Liu, G. J.; Gui, D. W.; Zeng, F. J. Groundwater depth affects phosphorus but not carbon and nitrogen concentrations of a desert phreatophyte in Northwest China. Front Plant Sci 2018, 9, 338. https://doi.org/10.3389/fpls.2018.00338.

54. Nguyen, H. T.; Stanton, D. E.; Schmitz, N.; Farquhar, G. D.; Ball, M. C. Growth responses of the mangrove Avicennia marina to salinity: development and function of shoot hydraulic systems require saline conditions. Ann Bot 2015, 115, 397-407.

55. Chakrabarti, N.; Mukherji, S. Effect of Phytohormone Pretreatment on Nitrogen Metabolism in Vigna radiate Under Salt Stress. BioPlantarum 2003, 46, 6366.

56. Baki, A. E.; Siefritz, F.; Man, H. M.; Weiner, H.; Kaldenhoff, R.; Kaiser, W. Nitrate reductase in Zea mays under salinity. Plant Cell Environ 2001, 23(5), 515521.

57. Ding, X. D.; Tian, C. Y.; Zhang, S. R.; Song, J. Effects of $\mathrm{NO}_{3}{ }^{-}-\mathrm{N}$ on the growth and salinity tolerance of Tamarix laxa Plant Soil $2010,331,57-67$.

58. Hameed, M.; Basra, S. M. A.; Ahmad, M. S. A.; Naz, N. Plant adaptation and phytoremediation. In:Ashraf M(ed) Structural and functional adaptations in plants for salinity tolerance. Springer, Netherlands, 2010; pp. 151-170.

59. Iqbal, N.; Umar, S.; Khan, N. A. Nitrogen availability regulates proline and ethylene production and alleviates salinity stress in mustard (Brassica juncea). J Plant Physiol 2015, 178, 84-91.

60. Ahanger, M. A.; Agarwal, R. M. Salinity stress induced alterations in antioxidant metabolism and nitrogen assimilation in wheat (Triticum aestivum) as influenced by potassium supplementation. Plant Physiol Bioch 2017, 115, 449-460.

61. Yu, T. F.; Feng, Q.; Liu, W.; Si, J. H.; Xi, H. Y.; Chen, L. J. Soil water and salinity in response to water deliveries and the relationship with plant growth at the lower reaches of Heihe River, Northwestern China. Acta Ecologica Sinica 2012, 32, 7009-701.

62. Li, X. R.; Tan, H. J.; He, M. Z.; Wang, X. P.; Li, X. J. Patterns of shrub species richness and abundance in relation to environmental factors on the Alxa Plateau: Prerequisites for conserving shrub diversity in extreme arid desert regions. Sci China Ser B 2009, 52, 669-680.

63. Fu, A. H.; Chen, Y. N.; Li, W. H. Water use strategies of the desert riparian forest plant community in the lower reaches of Heihe River Basin, China. Sci China Earth Sci 2014, 57, 1293-1305.

64. Rasband, W. S.; Image, J. National Institutes of Health, Bethesda. 1997-2016. https://imagej.nih.gov/ij/.

65. USSL Staff. Diagnosis and improvement of saline and alkali soils.USDA Handbook No 60.Washington DC, USA, 1954. p160.

66. Brian, G.; Peterson, P. C. Performance Analytics: econometric tools for performance and risk analysis. 2018; R package version 1.5.2. https://CRAN.Rproject.org/package=PerformanceAnalytics.

67. Grömping, U. Relative importance for linear regression in R: the package relaimpo. J Stat Softw 2006, 17, 1-27.

\section{Tables}

Table1: 
Site characteristics for different Lycium ruthenicum populations in the lower reaches of the Heihe River (Mean $\pm S D, n=3$ )

\begin{tabular}{|c|c|c|c|c|c|c|c|c|c|}
\hline No. & Desert types of plots & Longitude & Latitude & $\begin{array}{l}\text { Dominance } \\
\text { index }\end{array}$ & $\begin{array}{l}\text { Evenness } \\
\text { index }\end{array}$ & $\begin{array}{l}0-40 \mathrm{~cm} \text { Soil } \\
\text { Moisture } \\
(\%)\end{array}$ & $\begin{array}{l}0-40 \mathrm{~cm} \text { Soil Salinity }(\mathrm{g} \cdot \mathrm{kg} \\
\text { 1) }\end{array}$ & $\begin{array}{l}40-80 \mathrm{~cm} \\
\text { Soil } \\
\text { Moisture (\%) }\end{array}$ & $\begin{array}{l}40-80 \mathrm{~cm} \text { Soil Salinity }(\mathrm{g} \cdot \mathrm{kg} \\
\text { 1) }\end{array}$ \\
\hline$\square$ & Non-saline Gobi & $101^{\circ} 01^{\prime} 0.6^{\prime \prime}$ & $42^{\circ} 02^{\prime} 9.4^{\prime \prime}$ & $0.70 \pm 0.18 \mathrm{bc}$ & $0.54 \pm 0.28 \mathrm{ab}$ & $1.60 \pm 0.37 b$ & $3.09 \pm 0.44 \mathrm{bc}$ & $1.77 \pm 0.24 \mathrm{~d}$ & $0.83 \pm 0.37 \mathrm{C}$ \\
\hline 口 & Non-saline Gobi & $101^{\circ} 01^{\prime} 42.4^{\prime \prime}$ & $42^{\circ} 02^{\prime} 7.8^{\prime \prime}$ & $0.66 \pm 0.24 \mathrm{bcd}$ & $0.55 \pm 0.36 \mathrm{ab}$ & $4.33 \pm 1.61 \mathrm{ab}$ & $12.29 . \pm 1.69 \mathrm{abc}$ & $8.99 \pm 7.12 \mathrm{bcd}$ & $2.67 \pm 1.64 c$ \\
\hline$\square$ & Non-saline desert & $101^{\circ} 03^{\prime} 13.9^{\prime \prime}$ & $42^{\circ} 01^{\prime} 28.3^{\prime \prime}$ & $0.51 \pm 0.13 d$ & $0.66 \pm 0.13 \mathrm{ab}$ & $10.21 \pm 3.94 a$ & $13.84 \pm 2.87 \mathrm{abc}$ & $4.45 \pm 1.34 \mathrm{~cd}$ & $1.93 \pm 0.67 \mathrm{c}$ \\
\hline प & Non-saline desert & $101^{\circ} 02^{\prime} 42.0^{\prime \prime}$ & $42^{\circ} 03^{\prime} 11.8^{\prime \prime}$ & $0.86 \pm 0.21 \mathrm{a}$ & $0.27 \pm 0.37 \mathrm{~cd}$ & $14.60 \pm 3.20 \mathrm{a}$ & $11.34 \pm 1.49 \mathrm{abc}$ & $14.15 \pm 1.98 \mathrm{ab}$ & $1.28 \pm 0.26 \mathrm{c}$ \\
\hline$\square$ & $\begin{array}{l}\text { Very slightly saline } \\
\text { desert }\end{array}$ & $101^{\circ} 02^{\prime} 27.5^{\prime \prime}$ & $42^{\circ} 03^{\prime} 8.0^{\prime \prime}$ & $0.66 \pm 0.14 \mathrm{bcd}$ & $0.69 \pm 0.20 \mathrm{ab}$ & $16.68 \pm 11.4 \mathrm{a}$ & $34.12 \pm 0.76 a$ & $11.04 \pm 4.67 \mathrm{abc}$ & $7.15 \pm 1.16 \mathrm{~b}$ \\
\hline$\square$ & Non-saline desert & $101^{\circ} 16^{\prime} 59.3^{\prime \prime}$ & $42^{\circ} 02^{\prime} 17.8^{\prime \prime}$ & $0.80 \pm 0.09 \mathrm{ab}$ & $0.51 \pm 0.17 \mathrm{bc}$ & $15.51 \pm 3.85 a$ & $1.94 \pm 0.35 \mathrm{c}$ & $3.49 \pm 0.14 \mathrm{~cd}$ & $0.69 \pm 0.01 \mathrm{c}$ \\
\hline प & $\begin{array}{l}\text { Very slightly saline } \\
\text { desert }\end{array}$ & $101^{\circ} 00^{\prime} 52.5^{\prime \prime}$ & $42^{\circ} 06^{\prime} 56.8^{\prime \prime}$ & $0.94 \pm 0.11 \mathrm{a}$ & $0.16 \pm 0.26 \mathrm{~d}$ & $4.67 \pm 2.23 \mathrm{ab}$ & $27.39 \pm 4.41 \mathrm{ab}$ & $6.46 \pm 3.86 \mathrm{bcd}$ & $2.67 \pm 0.33 c$ \\
\hline a & Slightly saline desert & $101^{\circ} 00^{\prime} 3.7^{\prime \prime}$ & $42^{\circ} 06^{\prime} 52.0^{\prime \prime}$ & $0.63 \pm 0.09 \mathrm{~cd}$ & $0.80 \pm 0.15 \mathrm{a}$ & $7.96 \pm 4.26 \mathrm{ab}$ & $42.24 \pm 1.01 \mathrm{a}$ & $19.00 \pm 0.39 a$ & $15.61 \pm 0.80 \mathrm{a}$ \\
\hline
\end{tabular}

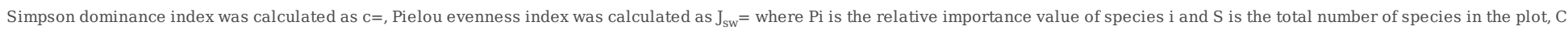

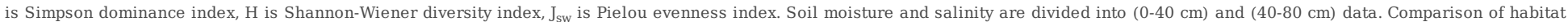

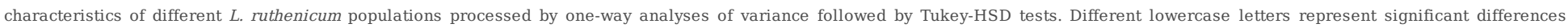
$(P<0.05)$. According to the literature (USSL Staff 1954), the soil salinization was divided into three categories (Non-saline; Very slightly saline; Slightly saline).

Table 2:

Leaf functional traits of different Lycium ruthenicum populations (Mean $\pm S D, n=3$ )

\begin{tabular}{|c|c|c|c|c|c|c|c|c|c|c|c|c|c|c|}
\hline No. & LT & SLV & SLA & LDMC & Suc & LD & TWC & RWC & $\mathrm{C}$ & $\mathbf{N}$ & $P$ & $\mathrm{C}: \mathrm{N}$ & $\mathrm{C}: \mathrm{P}$ & $\mathrm{N}: \mathrm{P}$ \\
\hline a & $1.03 \pm 0.01 \mathrm{c}$ & $6.69 \pm 0.47 \mathrm{bc}$ & $0.007 \pm 0.43 a$ & $141.5 \pm 13.4 \mathrm{ab}$ & $0.83 \pm 0.03 b$ & $0.15 \pm 0.01 \mathrm{ab}$ & $83.15 \pm 0.01 \mathrm{~cd}$ & $81.32 \pm 0.01 b$ & $347.5 \pm 0.42 \mathrm{a}$ & $13.57 \pm 0.06 \mathrm{c}$ & $3.98 \pm 0.16 \mathrm{~b}$ & $25.79 \pm 0.42 \mathrm{c}$ & $85.0 \pm 4.05 \mathrm{c}$ & $3.42 \pm 0.16 \mathrm{~b}$ \\
\hline a & $1.14 \pm 0.10 \mathrm{bc}$ & $7.00 \pm 0.67 b c$ & $0.006 \pm 0.47 \mathrm{a}$ & $147.5 \pm 5.1 \mathrm{ab}$ & $0.99 \pm 0.04 \mathrm{ab}$ & $0.14 \pm 0.01 \mathrm{ab}$ & $82.0 \pm 0.01 \mathrm{~cd}$ & $78.85 \pm 0.03 c$ & $337.8 \pm 0.29 a$ & $14.84 \pm 0.43 \mathrm{~b}$ & $3.09 \pm 0.00 \mathrm{~b}$ & $23.34 \pm 0.89 \mathrm{~d}$ & $107.5 \pm 2.5 \mathrm{c}$ & $4.80 \pm 0.14 \mathrm{ab}$ \\
\hline 口 & $1.26 \pm 0.00 \mathrm{abc}$ & $8.40 \pm 1.40 \mathrm{abc}$ & $0.006 \pm 1.11 \mathrm{a}$ & $144.7 \pm 11.3 \mathrm{ab}$ & $0.89 \pm 0.07 \mathrm{~b}$ & $0.12 \pm 0.02 b c$ & $82.26 \pm 0.01 \mathrm{~cd}$ & $78.46 \pm 0.02 \mathrm{c}$ & $342.4 \pm 0.29 a$ & $16.92 \pm 0.89 a$ & $1.53 \pm 0.91 \mathrm{c}$ & $20.28 \pm 0.74 \mathrm{e}$ & $435.8 \pm 25.5 a$ & $17.70 \pm 11.13$ \\
\hline a & $1.36 \pm 0.01 \mathrm{ab}$ & $7.81 \pm 0.19 \mathrm{abc}$ & $0.005 \pm 0.10 \mathrm{a}$ & $125.0 \pm 1.7 \mathrm{abc}$ & $1.03 \pm 0.03 \mathrm{ab}$ & $0.13 \pm 0.00 \mathrm{bc}$ & $83.13 \pm 0.00 \mathrm{~cd}$ & $70.41 \pm 0.00 \mathrm{c}$ & $324.1 \pm 0.12 \mathrm{~b}$ & $13.04 \pm 0.04 \mathrm{c}$ & $1.01 \pm 0.14 \mathrm{c}$ & $26.16 \pm 1.85 \mathrm{c}$ & $335.3 \pm 11.2 \mathrm{ab}$ & $13.16 \pm 1.76$ \\
\hline ㅁ & $1.26 \pm 0.23 \mathrm{abc}$ & $5.74 \pm 0.38 \mathrm{c}$ & $0.005 \pm 0.54 a$ & $197.9 \pm 21.0 \mathrm{a}$ & $0.90 \pm 0.04 \mathrm{~b}$ & $0.17 \pm 0.01 \mathrm{a}$ & $79.35 \pm 0.02 \mathrm{~d}$ & $94.81 \pm 0.00 \mathrm{c}$ & $337.6 \pm 0.16 a$ & $9.93 \pm 0.04 \mathrm{~d}$ & $0.81 \pm 0.00 \mathrm{c}$ & $34.34 \pm 0.48 \mathrm{~b}$ & $414.1 \pm 1.8 \mathrm{a}$ & $12.22 \pm 0.00$ \\
\hline 口 & $1.24 \pm 0.02 \mathrm{bc}$ & $7.38 \pm 0.13 \mathrm{bc}$ & $0.007 \pm 0.12 \mathrm{a}$ & $137.9 \pm 2.2 \mathrm{abc}$ & $0.87 \pm 0.03 \mathrm{~b}$ & $0.14 \pm 0.00 \mathrm{abc}$ & $84.91 \pm 0.00 \mathrm{bc}$ & $90.0 \pm 0.00 \mathrm{c}$ & $341.3 \pm 0.04 a$ & $15.07 \pm 0.27 \mathrm{~b}$ & $1.54 \pm 0.11 \mathrm{c}$ & $22.66 \pm 0.35 d$ & $223.3 \pm 13.1 \mathrm{bc}$ & $9.87 \pm 0.90 \mathrm{ab}$ \\
\hline 口 & $1.58 \pm 0.05 a$ & $9.14 \pm 0.64 \mathrm{ab}$ & $0.006 \pm 0.24 a$ & $153.1 \pm 7.5 \mathrm{bc}$ & $1.24 \pm 0.14 \mathrm{a}$ & $0.11 \pm 0.01 \mathrm{bc}$ & $88.37 \pm 0.01 \mathrm{ab}$ & $137.35 \pm 0.02 \mathrm{a}$ & $308.6 \pm 0.12 c$ & $15.15 \pm 0.17 b$ & $5.45 \pm 0.32 a$ & $20.56 \pm 0.30 \mathrm{e}$ & $58.1 \pm 1.1 \mathrm{c}$ & $2.79 \pm 0.20 \mathrm{~b}$ \\
\hline a & $1.37 \pm 0.01 \mathrm{ab}$ & $10.90 \pm 1.90 \mathrm{a}$ & $0.008 \pm 1.48 \mathrm{a}$ & $151.5 \pm 8.5 \mathrm{c}$ & $1.03 \pm 0.10 \mathrm{ab}$ & $0.09 \pm 0.02 \mathrm{c}$ & $87.95 \pm 0.01 \mathrm{a}$ & $130.36 \pm 0.01 \mathrm{~b}$ & $319.9 \pm 0.54 \mathrm{~b}$ & $8.43 \pm 0.34 \mathrm{e}$ & $2.87 \pm 0.00 \mathrm{~b}$ & $38.54 \pm 1.07 \mathrm{a}$ & $112.3 \pm 0.7 \mathrm{c}$ & $2.94 \pm 0.12 \mathrm{~b}$ \\
\hline
\end{tabular}

Multiple comparisons of traits between different populations using one-way analyses of variance followed by Tukey-HSD tests, Different letters represent significant

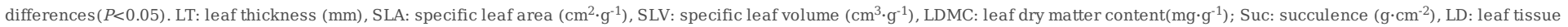
density $\left(\mathrm{g} \cdot \mathrm{cm}^{-3}\right)$, TWC: Total water content $(\%)$, RWC: relative water content $(\%)$, C: leaf carbon content $\left(\mathrm{mg} \cdot \mathrm{g}^{-1}\right)$, $\mathrm{N}$ : leaf nitrogen content $\left(\mathrm{mg} \cdot \mathrm{g}^{-1}\right)$, P: leaf phosphorus content $\left(\mathrm{mg} \cdot \mathrm{g}^{-1}\right)$.

\section{Additional File}

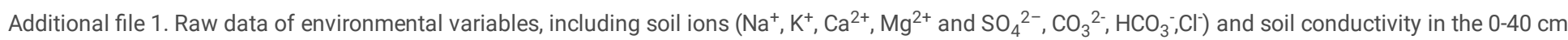
and $40-80 \mathrm{~cm}$ soil layers in the lower reaches of Heihe River, Northwest China.

\section{Figures}

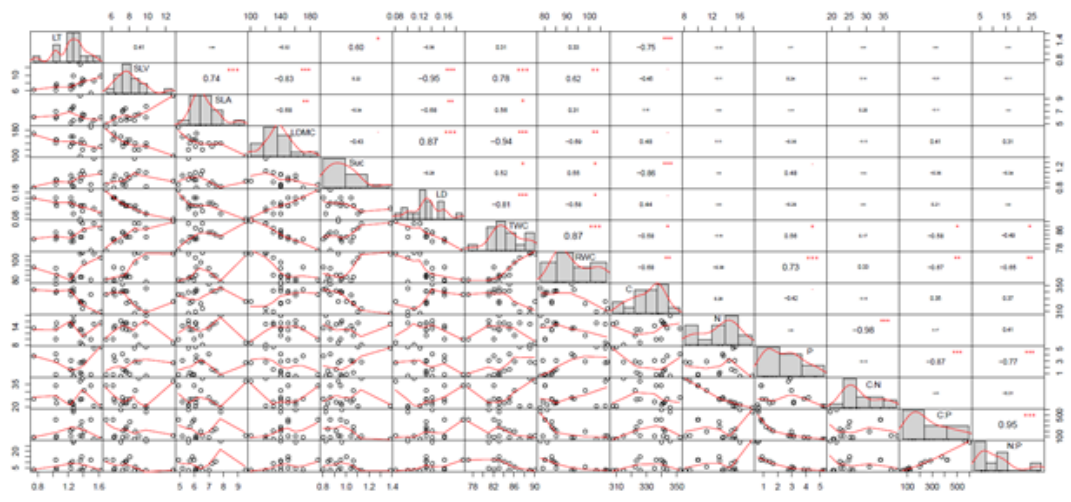

\section{Figure 1}

Correlation analysis among leaf functional traits and water-salt response. Drawing using R "PerformanceAnalytics" package. The numbers in the upper triangular region of the graph indicate correlation coefficients, and the asterisks indicate significance. The lower triangle is a linear regression between the two traits. LT:leaf thickness (mm), SLA囚specific leaf area (mm2/mg), SLV: specific leaf volume(cm3-g-1), LDMC: leaf dry matter content(mg-g-1); Suc: succulence ( $\mathrm{g}-\mathrm{cm}-2)$; LD: leaf dry matter concentation (g/cm3),TWC: Total water content(\%),RWC: relative water content(\%),C: organic matter content(mg/g), N: nitrogen content $(\mathrm{mg} / \mathrm{g}), \mathrm{P}$ : phosphorus content $(\mathrm{mg} / \mathrm{g}), \mathrm{C}: \mathrm{N}$ : the ratio of $\mathrm{C}$ and $\mathrm{N}, \mathrm{C}: \mathrm{P}$ : the ratio of $\mathrm{C}$ and $\mathrm{P}, \mathrm{N}: \mathrm{P}$ : the ratio of $\mathrm{N}$ and $\mathrm{P}$. 


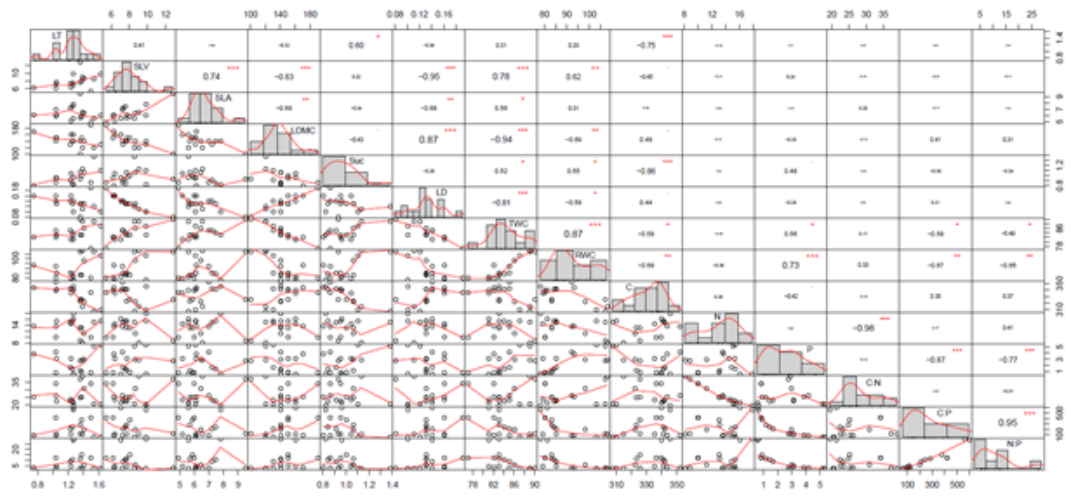

\section{Figure 1}

Correlation analysis among leaf functional traits and water-salt response. Drawing using R "PerformanceAnalytics" package. The numbers in the upper triangular region of the graph indicate correlation coefficients, and the asterisks indicate significance. The lower triangle is a linear regression between the two traits. LT:leaf thickness $(\mathrm{mm})$, SLA『specific leaf area $(\mathrm{mm} 2 / \mathrm{mg}), \mathrm{SLV}$ : specific leaf volume(cm3-g-1), LDMC: leaf dry matter content(mg-g-1); Suc: succulence ( $\mathrm{g}=\mathrm{cm}-2)$; LD: leaf dry matter concentation (g/cm3),TWC: Total water content(\%),RWC: relative water content(\%),C: organic matter content(mg/g), N: nitrogen content $(\mathrm{mg} / \mathrm{g}), \mathrm{P}$ : phosphorus content $(\mathrm{mg} / \mathrm{g}), \mathrm{C}: \mathrm{N}$ : the ratio of $\mathrm{C}$ and $\mathrm{N}, \mathrm{C}: \mathrm{P}$ : the ratio of $\mathrm{C}$ and $\mathrm{P}, \mathrm{N}: \mathrm{P}$ : the ratio of $\mathrm{N}$ and $\mathrm{P}$.
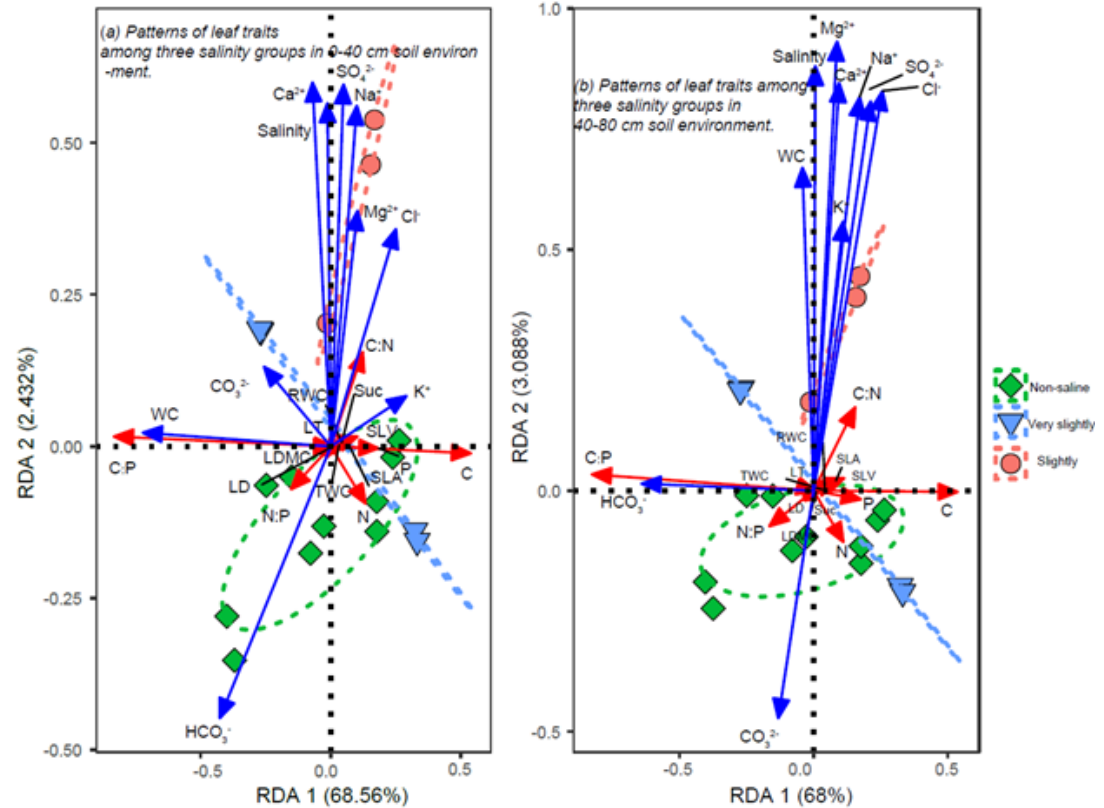

Figure 2

RDA of leaf functional traits and environmental variables of Lycium ruthenicum Murr populations in the lower reaches of the Heihe River. The red arrows are the leaf functional data, the blue arrows represent the soil traits that were included in the models as the underlying environmental factors. The direction of the arrow indicating a positive or negative correlation among the environmental factors with the ordination axes. The angle of the arrow reflects the strength of correlation between the environmental factors and functional traits, with small angles indicating strong correlations. Environmental variables include water (WC, 0-40 cm 40-80 cm soil), salinity (0-40 cm 40-80 cm soil) and soil ions ( $\mathrm{Na}+, \mathrm{K}+, \mathrm{Ca} 2+, \mathrm{Mg} 2+, \mathrm{CO} 32-, \mathrm{HCO}-, \mathrm{SO} 42-, \mathrm{Cl}-$ ).The dotted green circle represents the non-salt group, the blue circle represents the very mild salt group, and the red circle represents the mild salt group. 

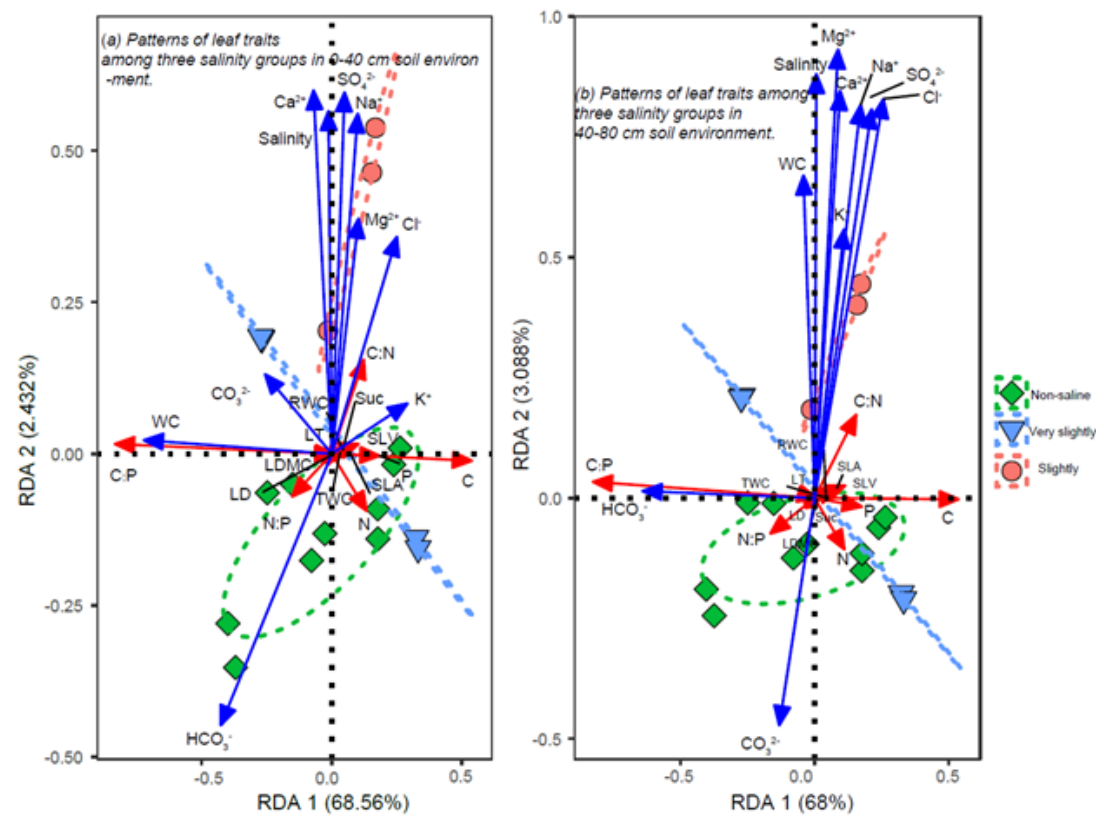

Figure 2

RDA of leaf functional traits and environmental variables of Lycium ruthenicum Murr populations in the lower reaches of the Heihe River. The red arrows are the leaf functional data, the blue arrows represent the soil traits that were included in the models as the underlying environmental factors. The direction of the arrow indicating a positive or negative correlation among the environmental factors with the ordination axes. The angle of the arrow reflects the strength of correlation between the environmental factors and functional traits, with small angles indicating strong correlations. Environmental variables include water (WC, 0-40 cm 40-80 cm soil), salinity (0-40 cm 40-80 cm soil) and soil ions ( $\mathrm{Na}+, \mathrm{K}+, \mathrm{Ca}+$ +, Mg2+,CO32-, HCO3-,SO42-, Cl-).The dotted green circle represents the non-salt group, the blue circle represents the very mild salt group, and the red circle represents the mild salt group.
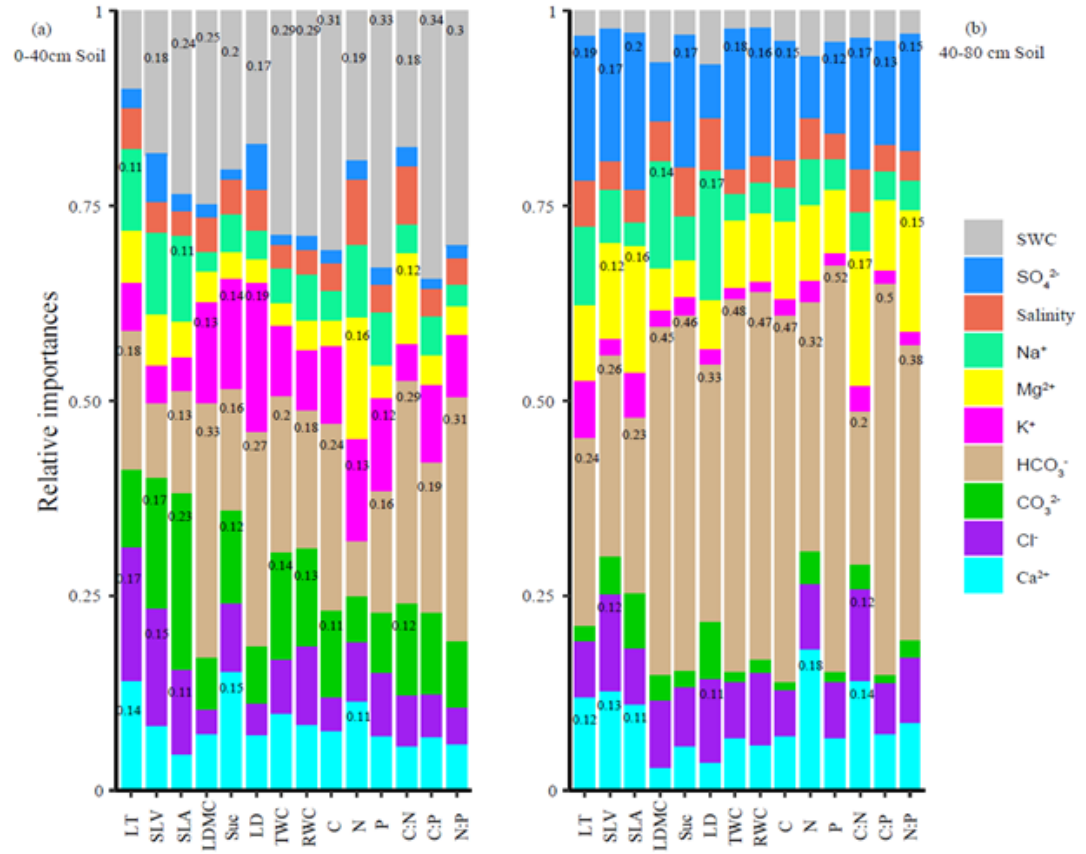

\section{Figure 3}

The relative importance of soil factors at different soil depths on leaf functional traits. The horizontal axis is leaf functional traits, and the vertical axis is the relative importance of soil factors. SWC: soil water content. The soil factors from top to bottom on the histogram are SWC, SO42-, Salinity, Na+, Mg2+, K+, HCO3-, $\mathrm{CO} 32-, \mathrm{Cl}-\mathrm{Ca} 2+$. Values below $10 \%$ are not shown in the Fig.3. 

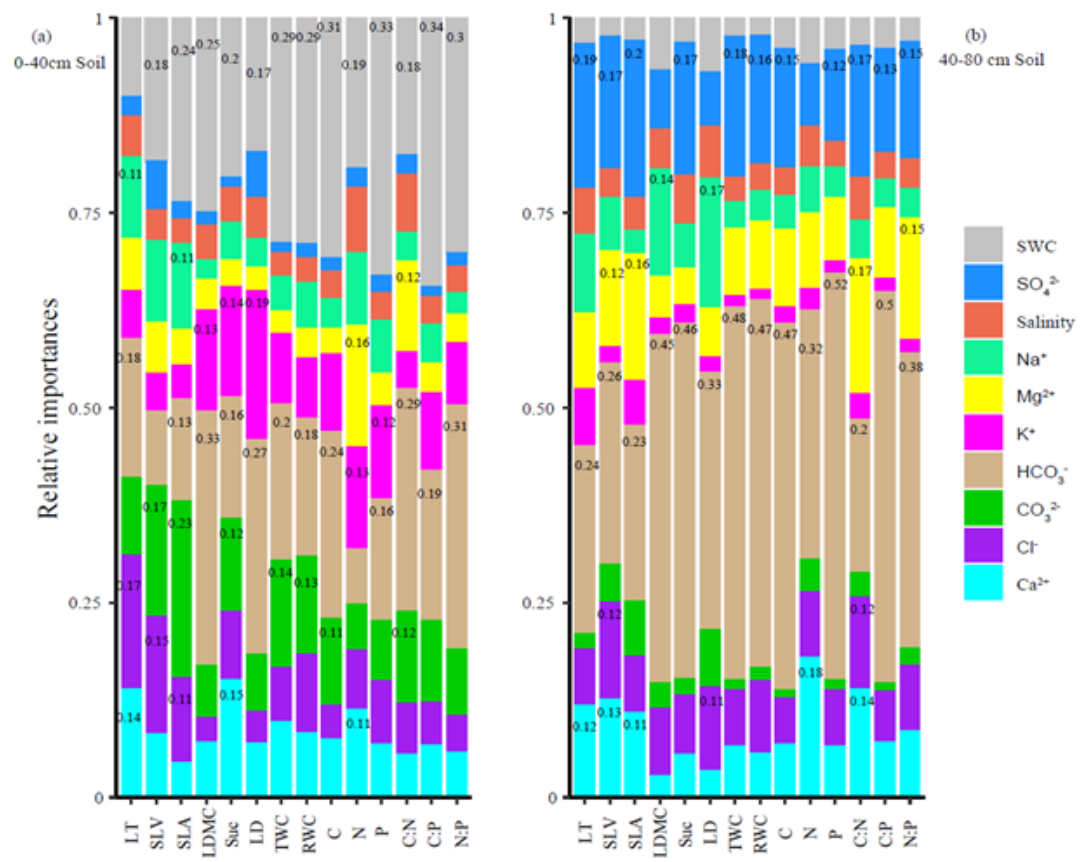

Figure 3

The relative importance of soil factors at different soil depths on leaf functional traits. The horizontal axis is leaf functional traits, and the vertical axis is the relative importance of soil factors. SWC: soil water content. The soil factors from top to bottom on the histogram are SWC, SO42-, Salinity, Na+, Mg2+, K+, HCO3-, CO32-, Cl-, Ca2+. Values below $10 \%$ are not shown in the Fig. 3.

\section{Supplementary Files}

This is a list of supplementary files associated with this preprint. Click to download.

- Additionalfile1.xlsx

- Additionalfile1.xlsx 